\title{
The Power of Ideas: The Fórum da Liberdade, 1988-2018
}

\author{
Camila Feix Vidal ${ }^{*}$ \\ Jahde Lopez ${ }^{* *}$ \\ Luan Brum ${ }^{* * *}$
}

\begin{abstract}
This is a study of the Fórum da Liberdade (FL), an annual event organised by the Brazilian think tank Instituto de Estudos Empresariais, an Atlas Network partner. Based on critical theory, this study is aimed at casting light on the role played by the FL in promoting US hegemony in the realm of ideas. Drawing on an analysis of all the forums over 30 years from its inception in 1988 until 2018, we demonstrate that this hegemony is based on the neoliberal economic model. We examine the presenters, the sponsors, the main themes and the award winners. We find that a) the FL privileges speakers who support the neoliberal ideal - mostly male politicians, entrepreneurs, and members of neoliberal think tanks in Brazil and elsewhere; b) the FL has been internationalising, embracing an absolute majority of speakers from the USA, and strengthening ties with its major partner, the North American Atlas Network; c) the FL helps build electoral platforms by privileging politicians who support its economic ideals; and d) the FL promotes the US neoliberal agenda via financial support from the entrepreneurs who fund the annual events, and an 'intelligentsia' that legitimises the ideas presented at those events.
\end{abstract}

Keywords: Fórum da Liberdade; think tanks; Atlas Network; neoliberalism; Critical Theory.

\section{Introduction}

This study aims to link the existing consensus about the role of the US academic domain in International Relations (IR), specifically in respect of major IR theories (Hoffman 1977; Tickner 2003; Acharya and Buzan 2010; Tickner and Inoue 2016; Villa et al 2017), to an empirical case, namely the role of think tanks in promoting the neoliberal ideal. Noting, in the words of Bourdieu and Wacquant (1992), that theory without the empirical is blind, we seek to provide a critical theory perspective in IR with an empirical dimension.

\footnotetext{
* Federal University of Santa Catarina (UFSC), Florianópolis-SC, Brazil; camilafeixvidal@gmail.com. ORCID iD 0000-0003-2205-4686.

** Federal University of Rio Grande (FURG), Rio Grande-RS, Brazil; jahdelopez@gmail.com. ORCID iD 0000-0001-9347-1183.

*** Federal University of Rio Grande (FURG), Rio Grande-RS, Brazil; luan.brum1996@hotmail.com. ORCID iD 0000-0002-1841-5445.
} 
This study forms part of a larger research project aimed at analysing neoliberal ${ }^{1}$ think tanks in Latin America that are partners of the North American Atlas Network. Although relatively new, the Atlas Network plays an important role in coordinating and promoting a neoliberal agenda by building ties with foreign think tanks. More generally, this study aims to illuminate the dominance of the USA in the realm of ideas, specifically its maintenance and promotion of the neoliberal economic model. The subjects of the study are Brazilian think tanks (or 'institutes') which propagate certain doctrines, values and goals. Specifically, our research is centred on a prominent neoliberal forum in Latin America, the Fórum da Liberdade (FL), an annual event organised by the Instituto de Estudos Empresariais (IEE), an Atlas Network partner. Based in Porto Alegre in southern Brazil, the institute is regarded as one of the 150 most important organisations that influence transformations in politics, societies and economics (Global Go to Think Tanks 2013).

Specifically, we present data about the FL's composition from its first meeting in 1988 until 2018, focusing on the themes for the panel discussions, the panelists' backgrounds, the linkages between speakers and sponsors, the level of internationalisation of the event, and connections with the USA. In doing so, we present empirical evidence of the ties between agents in the USA and Brazil, as well as possible relations among those agents and their economic and political interests. As such, this study develops the hypothesis that the FL is an instrument for influencing political and economic discourses and practices in ways that promote US national interests.

The database comprises documents published by the IEE, as well as records of each of the FL's 31 annual events in the period under review. We start with a theoretical discussion of the Atlas Network's role as a dominant hegemonic structure, and the roles of neoliberal think tanks in peripheral countries in promoting practices of 'consensus.' Next, we present our analysis of the FL's panel discussions and round table sessions. Comments follow on the internationalisation of the FL and its linkages with the USA. We when identify the ties between sponsors, panelists and prize winners, followed by a conclusion. Our analysis indicates that the FL plays an important role in promoting US interests, notably the North American neoliberal agenda.

\section{Hegemony, pedagogical colonialism and subordination: the role of the Atlas Network}

Departing from a neo-Gramscian perspective, this study develops the understanding that the ruling class legitimises itself by persuading a society to think in a certain way - normally one that reproduces the status quo, including current economic and social inequalities (Gramsci 1971). One of Antonio Gramsci's main contentions is that 'ideas' and 'culture' do not develop spontaneously or naturally, but are diffused in an organised way by the ruling class through the work of intellectuals that play a leading social role. As such, each class creates its own intellectuals who help to develop an awareness of and legitimate its economic interests. As Gramsci (2001: 21) argues, 
The intellectuals are the agents of the dominant group who exercise subaltern functions by the social hegemony and the political government, that is: 1) from the 'spontaneous' consensus given to the masses to the orientation expressed by the fundamental dominant class with regards to the social life-consensus that historically arises from 'prestige' (and, therefore, from trust) obtained by the dominant group because of its position and its function in the world of production; and 2) from the state coercion apparatus that 'legally' maintains the discipline of the groups that 'do not consent.'2

In this sense, the current domination of the ruling class is not maintained by coercion alone, but also by consensus, via a range of social institutions that serve to justify and legitimise the dominant system (Cox 1981). Utilising a combination of coercion and consensus, hegemonic and hierarchical structures are created and disseminated in a process of institutionalisation, constructing a legitimacy that enables the maintenance of the dominant class in a reciprocal rather than unilateral relation (Cox 1981). Therefore, hegemony in the global arena is understood as a mode of domination in which the dominant state creates a world order that is consistent with its own ideology and values, reproducing this same hegemony and its dominant class through practices of consensus realised by the peripheral (or subaltern) states.

As such, the current global hegemony manifests itself as a model of social relations based on a centre-versus-periphery structure in which a small centre owns the financial resources, while the periphery is responsible for the production and reproduction of dependent components (Cox 1981). As Gullo (2018: 191) argues, imperial practices developed by global hegemonies are closely linked to the global financial oligarchy, which becomes evident when we identify the cultural and ideological subordination practices that arise from the neoliberalist ideology and discourse:

Ideological subordination is generally carried out by great powers allied with international financial oligarchy and maintains the political unities that own less power as privileged victims, named coarsely as 'peripheral countries.' From an economic point of view, the ultimate purpose of ideological subordination is to persuade the population as a whole of the intrinsic uselessness of state intervention in the economy.

For Arturo Jauretche (1975), countries subjected to ideological subordination live in a type of 'neocolonialism' or 'pedagogical colonisation'3 driven by a group of 'native' intellectuals as a tool of domination. This group, also called the 'intelligentsia, comprises native intellectuals whose mentality has been conquered by the economic and political ideology of the dominant power, and which guarantees (more effectively than forceful occupation) the subordination of semi-colonial states. Nevertheless, this group of intellectuals is not passive. Despite being co-opted via pedagogical colonisation, they actively diffuse and reproduce the dominant agenda. For Brzezinski, cultural ideological domi- 
nance has never been taken as far and been as successful as that of the USA. As such, while the North American way of thinking has spread throughout the world, it has also created conditions for an indirect and consensual US hegemony. Therefore, this hegemony generates a complex structure of institutions and procedures designed to generate consensus and obscure inequalities in terms of power and influence (Brzezinski 1998: 36). For Loic Wacquant (2003: 9),

America holds this exceptional characteristic of being, on the threshold of the $21^{\text {st }}$ century, the first society in history gifted with the material and symbolic means to impose its thoughtless social and political [sic] as a universal structure of thought, and, when producing it, transmuting its particularities into norms, and even in a trans-historical ideal. And to make them, next, to emerge, transforming every part the reality of its image.

More explicitly, the current hegemony, with the USA at its centre, has sought to minimise more direct interventions (such as those in Central America at the beginning of the $20^{\text {th }}$ century and political and economic destabilisation in South America from the mid$20^{\text {th }}$ century onwards) while stepping up ideological persuasion techniques that promote its interests. As Luiz Alberto Moniz Bandeira (2018: 312) argues:

The very same persistence that took Washington authorities to imagine that the 'colour revolutions' model, initially well succeeded in Georgia (Pink revolution, 2003), Ukraine (Orange revolution, 2004), and Kyrgyzstan (Tulip revolution, 2005) could be reproduced in other countries as a type of subversive war to the achievement of its economic and geostrategic goals.

Proceeding from a generic relationship between the financial oligarchy, politicians and academics, institutions are built to disseminate the neoliberal capitalist ideal in a type of neocolonialism which Gill (1995) describes as 'market civilisation' - the global 'common sense' built from an Anglo-Saxon capitalist hegemony that disseminates and values deregulation and free markets as desirable for everyone, but actually serves to maintain the dominance of the ruling class as well as the hegemonic state. According to Wacquant (Wacquant and Lins 2003: 11), the 'invention' of the neoliberal ideal rests on the 'theoretical and practical engine for coding and transnationally propagating an ideological project that aims to submit the aggregation of human activities to the market's tutelage.' For Bourdieu (2003: 17), 'in the fight for the legitimate dominion of the world, the capital currently rests in Harvard or Chicago which assemble and combine, besides powerful scientific knowledge, a net of cultural products with universal claim.'

In recent years, a North American think tank has played a key role in diffusing the hegemonic ideology in peripheral countries (which either consent to or are compelled to accept it) in a type of cultural and ideological subordination. The Atlas Network, formally the Atlas Economic Research Foundation, was founded in 1981 by the English entrepre- 
neur Antony Fisher. Aiming to disseminate conservative economic ideals (such as the preservation of private initiative, meritocracy, free market, individual responsibility, private property and small government), it works with selected 'partner institutions' on every continent. It currently has 493 partners in 94 countries (Atlas Network 2019). However, since the Argentinean António Chafuen rose to the Atlas presidency in 1991, the network had concentrated on Latin America, partnering with 83 institutes in the region, and establishing the first (and until recently the only) Atlas regional centre, namely the Atlas Network Center for Latin America in November 2018. Atlas has 15 partners in Brazil alone. ${ }^{4}$

Ironically, this libertarian think tank is kept alive by US federal government resourc$\mathrm{es}^{5}$ as well as sympathetic entrepreneurs. ${ }^{6}$ It propagates and exports US-friendly policies through its partners in other countries, building a 'sphere of influence' (Fang 2017) that cultivates libertarian economic ideals. It finances and trains foreign personnel in order to integrate existing institutes, or to establish new ones. To this end, Atlas supports neoliberal think tanks throughout the world, and promotes and finances courses about political management and mass mobilisation strategies that include techniques for influencing public opinion via social networks and online videos (Fang 2017). According to Cindy Cerquitella, director of Atlas Academic Leadership, 'The Atlas academic leadership provides various trainings focusing on mission development, reaching your audience, and the importance of achieving impact' (Atlas 2015). Indeed, the name 'Atlas Network' is self-explanatory.

Atlas thrives on political and economic crises (sometimes created by the very same 'partners'), which provide triggers for imposing its neoliberal agenda. ${ }^{7}$ Thus the Atlas president, Alex Chaufen, has commented as follows on recent corruption scandals in leftist governments in Latin America: 'There was an opening - a crisis - and a demand for change, and we had people who were well trained to exert pressure fin favour of certain policies' (cited in Fang 2017: n.p.). In fact, some leaders of the Movimento Brasil Livre, which played an important part in the impeachment of the democratically elected president Dilma Rousseff in Brazil, are members of Atlas partner institutes (Fang 2017; Atlas 2015).

According to Fisher and Phehwe (2013), in the year 2000 alone, Atlas disbursed about U\$30 million in scholarships and prizes, including the Dorian and Antony Fisher Award for the building of institutes; the Freda Utley Award for think tanks who spread the Atlas message in 'difficult' parts of the world; and the Templeton Freedom Award, given annually to winners in different categories. In Latin America, Atlas has handed out special awards since 2005: the Francisco Marroquin Award to students, the Francisco di Vitoria Award for ethics and values, and the Mighel Kast Award for free market solutions against poverty.

Another strategy used by Atlas is to encourage the political right to take on a new guise, as in the case of the Tea Party movement - supposedly a grass-roots movement not attached to entrepreneurs and businessmen - that has positioned itself against big government, and demands a new agenda. Carlos Goes (cited in Dixon 2016: n.p.), president of the Instituto Mercado Popular, has noted that neoliberal institutes in Brazil recruit and train individuals who will, in turn, build their own projects and institutes: 
They are involved in social movements, political parties, academia, and research institutions. They have their own blogs, but they also write for the mainstream media. This is great, because it gives a spontaneous and bottom-up structure to the movement.

For Cerquitella (cited in Atlas 2015), 'it has been thrilling to work with advocates for liberty in Brazil, [...] and even more exciting to see them putting those lessons into practice.'

This new political right, financed and supported by its North American 'mother/partner', utilises technology and the leveraged impacts of social media ${ }^{8}$ in a 'subversive and sneaky' way (Fang 2017) to destabilise governments that are unfriendly to US interests. ${ }^{9}$ For instance, at the start of Lula da Silva's presidency, there were three neoliberal think tanks in Brazil. Today, there are more than 30, and 15 are formal Atlas partners. ${ }^{10}$ Indeed, the Atlas Network itself mentions on its website the 'success' of Brazilian partners in the propagation of neoliberal ideals and the reformulation of the political agenda: 'an array of independent network partners in Brazil are doing the heavy lifting of reforming the intellectual climate and policy debate. Together, they are spreading the ideas of new and innovative libertarian ways, proposing practical and politically possible solutions to the current crisis' (Atlas 2019). Likewise, Atlas has financed the last six Fórums da Liberdade, and in 2007 nominated its institutional founder, the Instituto de Estudos Empresariais, for its biggest prize, the Templeton Freedom Award, as one of the 'most important global institutions in the defence of freedom.'

\section{The Fórum da Liberdade (FL)}

Created in 1984 in the south of Brazil by young entrepreneurs, ${ }^{11}$ with the financial support of big enterprises such as Gerdau, Localiza, Suzano Araújo, Ipiranga, Mendes Júnior, Stemac, Banco Itaú, Tam and Grupo Évora (Gros 2003; IEE 2017), the Instituto de Estudos Empresariais (IEE) is responsible for creating and maintaining the FL. Aiming 'to incentivise and prepare new leaders on the basis of a free market economy and free enterprise' (IEE 2017), and 'shape a leadership with entrepreneurial abilities', the IEE is based in Porto Alegre (RS, Brazil) and works as a centralised organisation with restricted membership in a type of 'closed society for the chosen ones' (Casimiro 2016: 282). In 2013, Global Go To Think Tanks described it has one of the 150 most influential organisations in transforming politics, societies and economies in the world.

Its forum, described by Forbes magazine in 2013 as 'the most important event for discussing ideas in Latin America' (FL 2018), is held in Porto Alegre every year. According to the organisers:

The event aims to analyse social, political, and economic issues through a broad debate of opinions as well as propositions of alternative paths in direction to a more free and wealthy society. Therefore, forged on the belief of a free and plural nation, the Fórum da 
Liberdade is an initiative that fosters culture and education in our country (FL 2018: n.p.).

At the last event studied, in 2018, panel discussions were attended by more than 5000 people, and live streaming videos were viewed by some 500000 more. At least 29 schools in Porto Alegre and 48 Brazilian universities subscribed to the event (FL 2018), testifying to its broad reach and its extensive ties with the academic world. The IEE itself has a long-standing partnership with a prestigious university in Porto Alegre, the Pontífica Universidade Católica do Rio Grande do Sul (PUCRS), where all the 2018 events took place. As its themes reflect, the FL has become an important propagator of the neoliberal agenda in Brazilian society.

\section{Recurrent themes}

When we set out to study the themes of FL sessions and panel discussions, we encountered a problem, namely a lack of information about the early events. No information is available about the panel discussions from 1988 to 2007. The titles of panel discussions are available from 2008 onwards, as Appendix I shows. The themes cover not only economics, but encompass politics and social issues as well. The theme of the first forum, in 1988, is revealing: 'Politics, Economics and Social Issues in Brazil.' Nevertheless, classical liberalism (libertarianism or neoliberalism) remains the dominant subject. ${ }^{12}$ Panel titles such as 'The Free Market,' 'International Free Trade,' 'Brazil's Cost,' and 'Who Is the Market' point to the neoliberal bias that runs through all the forums.

However, the FL not only addresses economic issues, but Brazilian social issues as well. Panel titles such as 'The Brazilian Social Crisis,' 'The Education Crisis', and 'Civilisation or Barbarism' reflect a pessimistic approach to social issues, and point to solutions drawn from classical liberal perspectives. Panel titles on political issues typically refer to problems, and imply that fresh solutions will be offered. Panel titles such as 'The Democracy Challenge,' 'The Rights and Duties of Governments,' 'Corruption in Brazilian Government' are examples of how the FL positions itself as an authority on governance and political systems. Therefore, it promotes not only n economic agenda, but also a political and social one.

The FL has proven to be an excellent platform for showcasing certain political candidates, mostly allied to the neoliberal cause. At the first forum, the future Brazilian president Fernando Collor de Mello delivered a lecture. The next year, in 1989, the forum presented a panel discussion among three presidential candidates: Leonel Brizola, Mário Covas and Luís Inácio Lula da Silva. More recently, in 2014, Aécio Neves (runner-up in the presidential race in 2014) led a special panel discussion at the start of the forum, and in 2017, João Dória, the governor of São Paulo, delivered the opening address. Henrique Meirelles, finance minister and presidential candidate, became a regular speaker at the FL, participating in round table and panel discussions, including the 'special panels' that opened and closed the event in 2008 and 2010. Eduardo Campos, a presidential candidate in the 2014 elections, and the former president Fernando Henrique Cardoso also lectured 
at the event. Initially, the FL tried to adopt a more egalitarian stance, providing a platform for candidates from the entire political spectrum, as in 1989 when representatives of the political left were present. In recent years, however, this supposedly democratic approach was replaced with a narrower selection of candidates, who were invited to air their views and political ideals. In 2018, for example, a panel discussion featuring presidential candidates comprised João Amoedo, Flávio Rocha, Geraldo Alckmin, Ciro Gomes and Marina Silva (Jair Bolsonaro was invited, but did not attend), but omitted almost all left-wing candidates.

Lastly, we cannot overlook the role of the FL in promoting certain political strategies. In 2015, when part of Brazilian society went to the streets with banners against corruption and in favour of 'less Marx, more Mises', the special panel was titled 'Liberdade de Expressão: \#NasRuasPelaLiberdade' (Freedom of Expression: In the Streets for Liberty). Those in charge of the panel were Marcel Van Hattem, then state deputy and currently federal deputy known for his tireless minimal government campaign; and Kim Kataguiri, a former member of Students for Liberty, founder of MBL, and recently elected state deputy. As Hélio Beltrão - a diligent speaker at FL events - noted, 'It's like a soccer team; the defense is the academy, and the politicians are the offense. We have already scored some goals [a reference to Dilma's impeachment]. The midfield would be the culture people, those that form public opinion' (cited in Fang 2017: n.p.).

Besides serving as an electoral platform, then, the FL also serves to approve and legitimise certain political strategies, as was the case with this last panel. If there is any doubt about the role played by the FL to propagate neoliberal ideals, and promote politicians who share these ideals, the following statement by Marcel van Hattem will be enlightening: 'If today I am a deputy', he declared, 'I also owe it to the Fórum da Liberdade' (cited in Amaral 2015: n.p.).

An unexpected result of our analyses of themes and presentations was the relationship between the titles of panel discussions, and the people who led those discussions. We have concluded that panelists are chosen in a very specific way - either because they represent a neoliberal point of view, or because they are FL regulars with no relationship with the theme in question. That is, speakers are not necessarily invited because of their knowledge or expertise, but because they can be relied upon to promote the FL's ideology. Far from being a 'forum of ideas' or a 'plural space,' then, the FL events are targeted towards a single idea, namely neoliberalism. ${ }^{13}$

In 2008, for instance, Luiz Carlos Molion - one of few academics in Brazil that deny the existence of global warming - was invited to open a panel discussion on 'Global Warming or History'. Similarly, in 2007, the FL invited one of few African participants, the Kenyan James Shikwati, known for his opposition to foreign aid to underdeveloped African countries, in opposition to noted African academics, politicians and civil society leaders. Panel discussions about public spending are also biased towards a particular approach. In 2013, members of Iceland's Central Banking Council (who were involved in the 2008 financial crisis) and the CEO of the Ayn Rand Foundation were invited to speak on this subject. 
Nevertheless, perhaps the most symbolic panel is the one on education - a perennial subject, for FL speakers are selected in a very specific way in order to promote an idea of education that values private universities instead of public ones. (The most prestigious education institutions in Brazil are supported by the Federal government.) That was the case with the panel entitled 'The Education of the Future' (2011), led by the CEO of Anhanguera; and the panel entitled 'Education and Meritocracy' led by the CEO of Kroton Educational, a giant North American company active in the Brazilian education sector.

Other panels on the same subject relied on speakers without the authority to deal with the subject. In 2013, for example, the main speaker on 'Basic Education' was a best-selling author on personal finances, and, in 2014, a Veja columnist. By contrast, important panels, especially opening or closing panels about projects for the future, rely on prominent business people. Thus the 2012 panel on 'Which Kind of Brazil Will be Yours?' was presented by Roger Agnelli, CEO of Vale, and André Johannpetter, CEO of Gerdau.

The triad of 'society, politics and economics' has been present at all FL events, reflecting the fact that perspectives on politics and society are part of the neoliberal economic perspective. When speakers criticise certain political models or politicians, this is done in terms of neoliberal values and practices. In the same way, when speakers propose that the Brazilian education system should be rethought, this is done in a way that values private institutions. Lastly, far from being a 'plural' event, the FL is structured to present, propagate and legitimise (through a certain 'intelligentsia') the neoliberal agenda, intrinsically tied to US foreign policy interests. It is no accident that the great majority of foreign panelists are from the USA.

\section{Speaker profiles}

Drawing on data on the FL and IEE websites, we arrived at a number of 471 speakers from the first forum in 1988 until the most recent in 2018. Analysing the speakers' profiles was one of the most difficult tasks in conducting the research. Firstly, many speakers come from abroad, which meant their profiles were often in foreign languages. Secondly, it was also sometimes difficult to identify the speakers from the names recorded by the FL. At times, it publishes incomplete names or nicknames only, as in the case of the Brazilian speakers Peninha, Bernardinho and Lobão. Even though the authors know who these speakers are, and can search for their profiles, this is more difficult when dealing with speakers from other countries. Moreover, in some cases we found two or more individuals with the same name. Thirdly, we had to deal with a heterogeneous group of individuals ranging from the founder of a reggae band to lawyers, theologians and homeopaths.

We dealt with these obstacles in the following ways. First, we did not consider the profiles of individuals whose identities we were not certain of, given the name provided by the FL and the names we found online. Second, we resorted to academic work and the Internet as our sources of information, choosing to focus on websites or profiles that are recognised in Brazilian academia, such as the Centro de Pesquisa e Documentação de História Contemporânea do Brasil (CPDOC) of the Fundação Getulio Vargas, Academia 
de Letras, the Senate, the Foreign Policy Ministry, the Legislative Chamber and the Federal government, as well as the websites of US universities, 'liberal' institutes, as in the case of Fórum da Liberdade and IEE, LinkedIn, and personal websites (such as those of the former Brazilian president Fernando Henrique Cardoso and Nelson Sirotsky). Thirdly, given that many speakers record more than one occupation, we chose to count all of them. Therefore, when reading Figure 1, attention should be paid to overlaps, since multiple occupations were considered. The data analysis showed that speakers were mainly male, professors, politicians, entrepreneurs, and members or directors of neoliberal institutes.

As shown by Table 1, the speakers from the first forum until 2018 were mostly male. From a total of 471 speakers, 448 were male $(95,2 \%)$ while only 23 were female $(4,8 \%)$. Twelve women were Brazilians, and 11 were foreigners, of which five were from the USA. Most of the forums featured no women speakers at all. The exceptions were a small number of forums where the same female speaker spoke over and over again, and the 2005 forum, when 20 of the speakers were women.

Figure 1 also shows the prevalence of occupations linked to academia (professors), politics (city councillors, deputies, senators, ministers, and presidents), and finance (businessmen and entrepreneurs), confirming the triad exposed in the theoretical work of Robert Cox, Stephen Gill, Marcelo Gullo and Arturo Jauretche, and briefly discussed in the introduction. Even more speakers were associated with neoliberal institutes, evidencing a homogenous circulation among the members of those institutes, as well as effective coordination.

Figure 1 - Speakers' occupations, 1988-2018

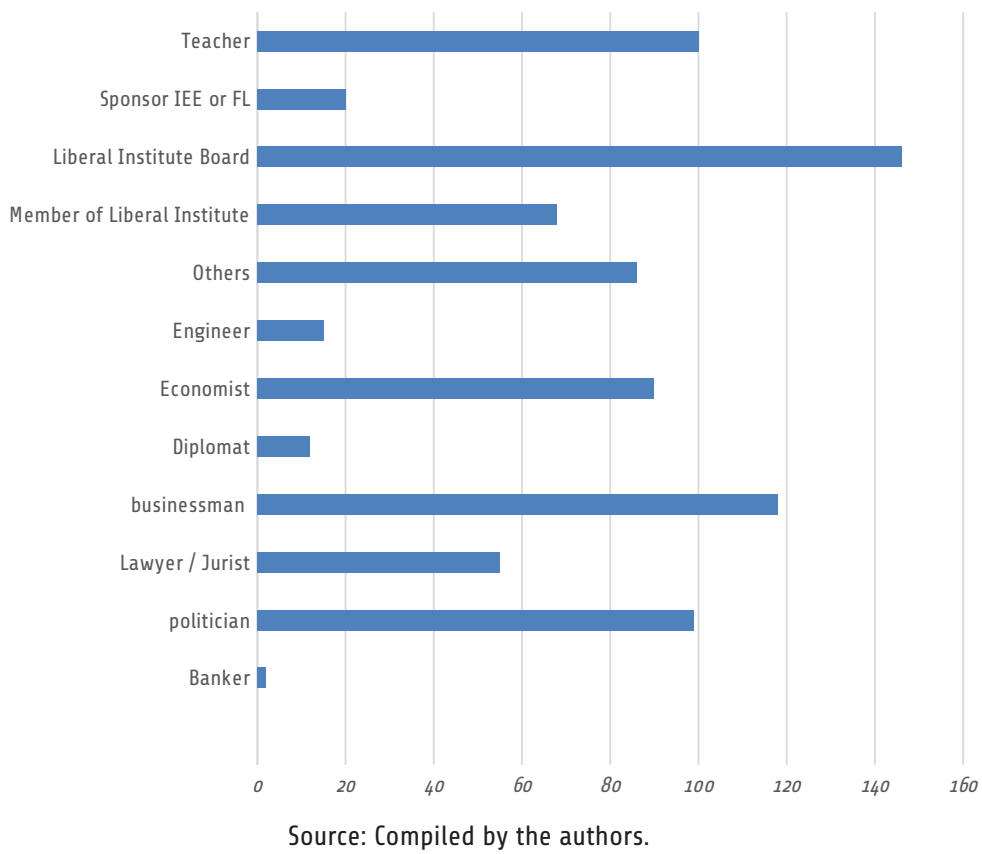


Table 1 - FI speakers by gender

\begin{tabular}{|c|c|c|c|}
\hline Year & Total & Men & Women \\
\hline 1988 & 15 & 15 & 0 \\
\hline 1989 & 16 & 16 & 0 \\
\hline 1990 & 20 & 20 & 0 \\
\hline 1991 & 14 & 14 & 0 \\
\hline 1992 & 14 & 13 & 1 \\
\hline 1993 & 12 & 12 & 0 \\
\hline 1994 & 8 & 8 & 0 \\
\hline 1995 & 8 & 8 & 0 \\
\hline 1996 & 6 & 6 & 0 \\
\hline 1997 & 7 & 6 & 1 \\
\hline 1998 & 5 & 5 & 0 \\
\hline 1999 & 10 & 10 & 0 \\
\hline 2000 & 12 & 12 & 0 \\
\hline 2001 & 22 & 21 & 1 \\
\hline 2002 & 18 & 18 & 0 \\
\hline 2003 & 17 & 17 & 0 \\
\hline 2004 & 11 & 10 & 1 \\
\hline 2005 & 20 & 14 & 6 \\
\hline 2006 & 13 & 12 & 1 \\
\hline 2007 & 16 & 15 & 1 \\
\hline 2008 & 14 & 14 & 0 \\
\hline 2009 & 15 & 13 & 2 \\
\hline 2010 & 18 & 18 & 0 \\
\hline 2011 & 16 & 16 & 0 \\
\hline 2012 & 16 & 15 & 1 \\
\hline 2013 & 22 & 22 & 0 \\
\hline 2014 & 19 & 19 & 0 \\
\hline 2015 & 23 & 19 & 4 \\
\hline 2016 & 23 & 23 & 0 \\
\hline 2017 & 18 & 17 & 1 \\
\hline 2018 & 23 & 20 & 3 \\
\hline Total & $471(100 \%)$ & $448(95,2 \%)$ & $23(4,8 \%)$ \\
\hline
\end{tabular}

Source: Created by the authors. 
If the speakers' occupations were relatively homogeneous (professor, entrepreneur, politician, and member of neoliberal institute), so were the speakers themselves. The same speakers appeared year after year, with the FL counting on the captive presence of businessmen such as Jorge Gerdau Johannpetter (12x) and Henry Maksoud (7x), the diplomat Roberto Campos (5x), the 'Chicago Boys' economists Paulo Rabello de Castro (8x) and Paulo Guedes (6x), the lawyer Ives Gandra Martins (5x), the economist Gustavo Franco $(5 \mathrm{x})$, the self-proclaimed philosopher Olavo de Carvalho $(5 \mathrm{x})$, and the Veja columnist Rodrigo Constantino (6x).

What this shows once again is that the supposed plurality of ideas mentioned on the FL website as its main characteristic does not materialise in practice. Indeed, the speakers are part of a specific, homogenous group: men, entrepreneurs, politicians, academics and members of neoliberal institutes. Many of them studied at the University of Chicago, and the vast majority of academics teach liberal economics (or neoliberalism). Most of the politicians support the free market. Lastly, many of the speakers from neoliberal institutes are the founders of such institutes in their own countries, as in the case of Barum Mitra from India and Alberto Mingardi from Italy. An unexpected finding was the link between the FL and some journalists, specifically the Veja columnist Rodrigo Constantino, as well as Nelson Sirotsky and David Coimbra from the RBS, a Rede Globo affiliate.

\section{Internationalisation and ties with the USA}

As shown by Figure 2, the forums have progressively become more international. While there were no foreign speakers at the first forum, at the last event (2018) almost half (nine out of 23) were from abroad. In 1997 and 2006, for instance, there were more speakers from abroad than from Brazil. In total, the forums featured 325 Brazilian and 146 foreign speakers - a significant number, if we consider that the foreigners represent a third of the total.

Figure 2 - National and foreign speakers at the FL, 1988-2018

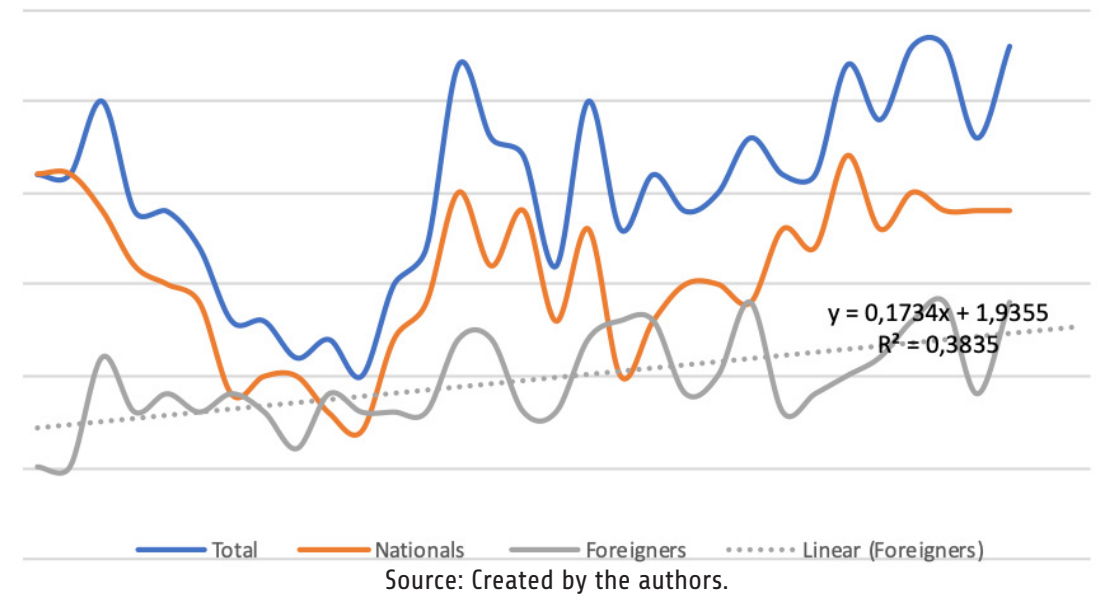


Figure 3 shows that 55 of 146 foreign speakers - more than a third - were from the USA. If we consider the Anglo-Saxon demographic, the proportion was even higher: a total of 72 from the UK, Australia, New Zealand, Canada and the USA. After the USA, Argentina with 16 speakers is a distant second. Given its geographic and linguistic proximity, Latin American representation is negligible: of the 146 international speakers, 53 came from 12 Latin American countries, a paltry number when compared to the number of speakers from the USA.

Figure 3 - FL speakers by nationality, 1988-2018

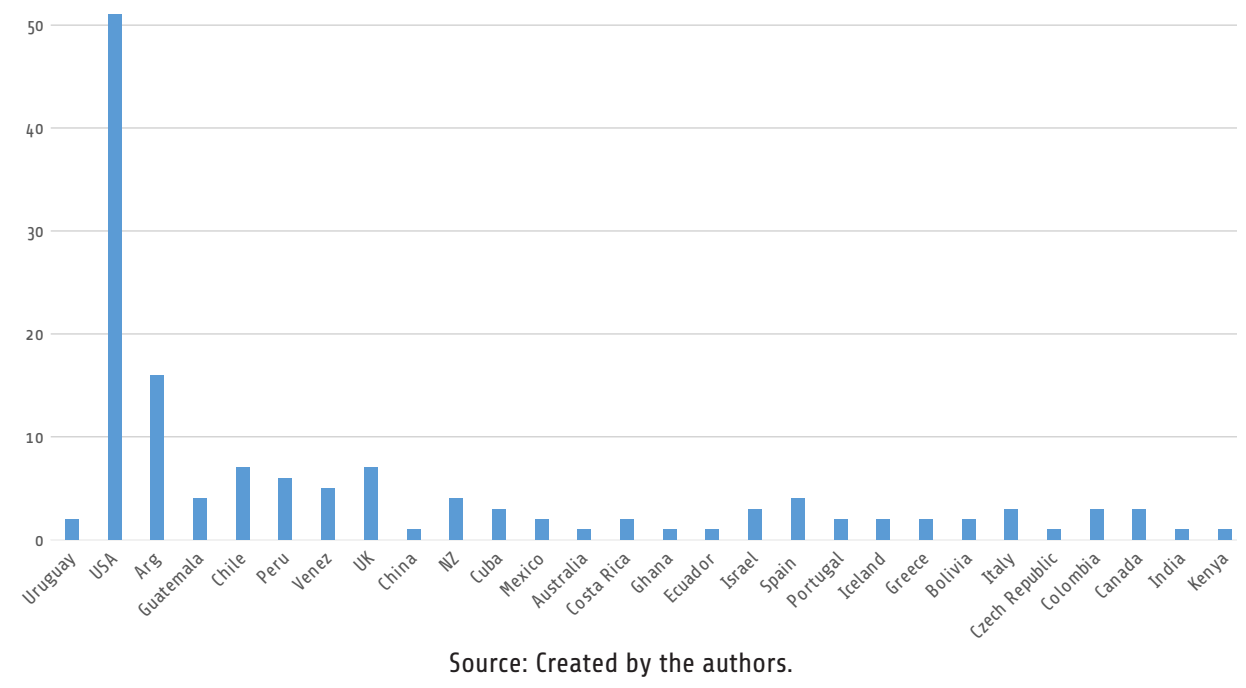

The massive US presence at a Brazilian forum of ideas reflects its active international role. This argument is corroborated by the ties of the 416 non-US speakers with the USA - that is, 325 Brazilians and 91 foreigners (except US nationals). Formal ties with the USA were recorded.

We found a close link between speakers and universities in the USA; that is, a significant proportion of Brazilian and foreign speakers (excluding US speakers) in the FL editions are or have been linked to US universities. Of the 416 speakers, 152 had completed an undergraduate, postgraduate and/or specialisation course at universities in the USA, and 110 panelists had completed graduate courses in the USA. If US nationals are included, the number rises to 207. This shows that nearly half of all speakers excluding those from the USA have ties with the US academic world. They include people from Brazil, other Latin American countries, Europe and Africa. 
Table 2 - Ties between national and foreign speakers (except US nationals) with US universities

\begin{tabular}{|c|c|c|c|c|c|c|c|}
\hline Year & Total & Undergrad & Postgrad & Special & $\begin{array}{l}\text { Univ. } \\
\text { council }\end{array}$ & Professor & Lecturer \\
\hline 1988 & 15 & 0 & 2 & 2 & 2 & 0 & 0 \\
\hline 1989 & 16 & 0 & 2 & 0 & 3 & 1 & 1 \\
\hline 1990 & 19 & 0 & 4 & 0 & 4 & 1 & 0 \\
\hline 1991 & 12 & 1 & 5 & 0 & 1 & 4 & 0 \\
\hline 1992 & 10 & 0 & 1 & 0 & 0 & 0 & 0 \\
\hline 1993 & 9 & 1 & 4 & 0 & 1 & 0 & 2 \\
\hline 1994 & 6 & 0 & 1 & 0 & 0 & 0 & 0 \\
\hline 1995 & 8 & 2 & 3 & 0 & 0 & 1 & 0 \\
\hline 1996 & 5 & 0 & 3 & 0 & 1 & 1 & 0 \\
\hline 1997 & 6 & 1 & 2 & 0 & 1 & 2 & 0 \\
\hline 1998 & 4 & 0 & 1 & 0 & 2 & 1 & 0 \\
\hline 1999 & 8 & 2 & 3 & 0 & 2 & 1 & 0 \\
\hline 2000 & 12 & 2 & 3 & 1 & 1 & 3 & 1 \\
\hline 2001 & 19 & 2 & 6 & 1 & 4 & 2 & 2 \\
\hline 2002 & 14 & 1 & 5 & 0 & 1 & 3 & 1 \\
\hline 2003 & 16 & 2 & 3 & 0 & 1 & 3 & 0 \\
\hline 2004 & 10 & 0 & 2 & 0 & 1 & 2 & 1 \\
\hline 2005 & 18 & 0 & 4 & 0 & 4 & 3 & 1 \\
\hline 2006 & 11 & 1 & 4 & 1 & 2 & 4 & 0 \\
\hline 2007 & 14 & 0 & 1 & 0 & 2 & 3 & 1 \\
\hline 2008 & 12 & 1 & 6 & 1 & 2 & 3 & 0 \\
\hline 2009 & 13 & 0 & 5 & 0 & 0 & 1 & 0 \\
\hline 2010 & 15 & 3 & 6 & 1 & 4 & 2 & 0 \\
\hline 2011 & 14 & 0 & 2 & 1 & 1 & 2 & 0 \\
\hline 2012 & 15 & 1 & 3 & 1 & 1 & 3 & 1 \\
\hline 2013 & 21 & 1 & 5 & 2 & 3 & 3 & 2 \\
\hline 2014 & 17 & 1 & 4 & 2 & 1 & 1 & 0 \\
\hline 2015 & 20 & 1 & 5 & 1 & 0 & 3 & 1 \\
\hline 2016 & 21 & 2 & 7 & 0 & 2 & 3 & 2 \\
\hline 2017 & 15 & 1 & 6 & 0 & 0 & 1 & 0 \\
\hline 2018 & 21 & 1 & 2 & 1 & 0 & 1 & 2 \\
\hline Total & 416 & 27 & 110 & 15 & 47 & 58 & 18 \\
\hline
\end{tabular}

Source: Created by the authors. 
As noted by neo-Gramscian critical theorists, the ties with the hegemonic academy not only co-opts the foreigner that carries within him the knowledge he has acquired and, as such, the hegemonic ideals for his home country; he also delivers this this ideology in a network that tends to grow and become more dense, reaching students, colleagues and researchers that will also be influenced. In this way, the co-opted 'intelligentsia, as Jauretche (1975) has noted, serves to reinforce hegemonic dominance while concealing the underlying dynamic of colonialism and ideological subordination.

Indeed, the role played by US universities as a mechanism of power in other countries is not new. Scholars of realism and interdependency have pointed to the importance of US universities as a means of propagating US national interests and co-opting other countries. According to Nye (2006: 17), 'The United States was converted into a major mecca for those who search for higher education. Approximately half a million foreign students come to the United States every day... it is possible to find US graduates in almost every chamber in the world.'

When we take into account that this high proportion of foreign speakers who have studied at US universities bring with them a world vision that is favourable to US interests, creating a network effect in their home country, it becomes easier to comprehend the current US hegemonic dominance and the building of 'practical knowledge' (Cox 1981). It is no accident that the university with the highest number of speakers in the FL is the University of Chicago. In fact, 33 panelists among Brazilians and foreigners (except US nationals) have studied and/or worked there. ${ }^{14}$

The data shows how neoliberalism advocacy is structured, and why it is present at the FL events. Lastly, an unexpected finding was the high number of speakers (especially Latin Americans) who have studied or taught at the Universidad Francisco Marroquín in Guatemala. Created in 1971 by Manuel Ayau, the first Latin American to become president of the Mont Pelerin Society, this private university is intended to educate the Guatemalan elite among others by promoting a classical liberalism ideology.

To summarise, the data shows that the FL has become more internationalised over the years, resulting in an ever higher number of international speakers; that far more speakers are from the USA than from other foreign countries; and that the speakers in general have close ties with US universities, led by the University of Chicago. We can now turn to the question of how the delivery of the neoliberal ideal is structured by the FL. In other words, who pays for the propagation of this 'market civilisation'?

\section{Sponsors and awards}

Our data covers an 11-year period, from 2008 until 2018. It shows that the sponsors are a very homogeneous group, who generally sponsor more than one event - in some cases, all the events, as does Gerdau.

Major sponsors include Itaú, Vonpar, Renner, the Atlas Network, Souza Cruz, CMP Celulose, Ipiranga, Grupo RBS, and Gerdau. While Gerdau has helped to sponsor all the events, Itaú and Santa Cruz sponsored the first in the period in question. Renner and the 
Atlas Network have each sponsored the last five events. Gerdau and Atlas have a presence on the panels as well, in the form of André Johannpetter, Gerdau's founder, and Alex Chafuen, the Atlas president.

Except for Ipiranga and Souza Cruz, all the other sponsors (Itaú, Vonpar, Renner, Atlas, CMP, RBS, and Gerdau) are members or directors of neoliberal institutes, and/or lectured during an FL event, evidencing that their linkage with the FL is not only one of sponsoring, therefore enabling the event, but also of putting together the event itself. As such, the vast majority of sponsors are tied to a neoliberal institute in Brazil or abroad, indicating a convergence between ideology and interest.

Figure 4 - Main sponsors, 2007-2018

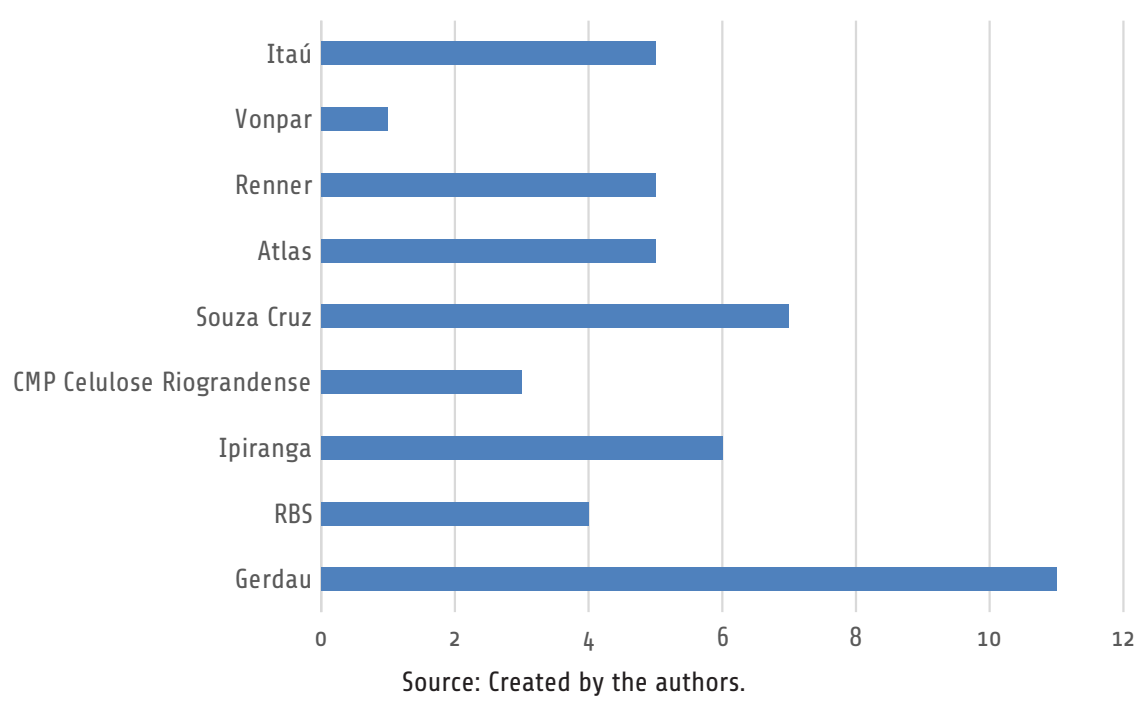

Awards also follow a repeated pattern. The most important award is the 'Prêmio Libertas', given out since 1997, as a celebration of the FL's $10^{\text {th }}$ anniversary and conferred on entrepreneurs who 'distinguish themselves in their work while valuing market economic principles and the respect for the rule of law' (FL 2018: n.p.). The vast majority of the 22 recipients between 1997 and 2018 were board members of neoliberal institutes in Brazil or abroad (14, or $58,4 \%$ from the total), followed by a significant number of sponsors (six, or $25 \%) .{ }^{15}$ Of 22 recipients, only four were not sponsors and not members of an institute board of directors:

Table 3 - Prêmio Libertas awards, 1997-2008

\begin{tabular}{cccc}
\hline & Board members of liberal institutes & Sponsor & None \\
\hline$N$ & 14 & 6 & 4 \\
\hline$\%$ & 58,4 & 25 & 16,6 \\
\hline
\end{tabular}

Source: Created by the authors. 
The meritocratic principle followed by the FL when conferring this award on its speakers is very specific: the recipients are mostly members of the boards of institutes with identical economic views, followed by the sponsors themselves. Among the board members, the IEE and Millennium predominate (each with six awards), followed by Instituto Liberdade.

Table 4 - Directors of institutes in receipt of the Prêmio Libertas

\begin{tabular}{lc}
\hline Institute & Number of directors awarded \\
\hline Instituto Ludwig von Mises & 2 \\
\hline Instituto Formação de Líderes & 1 \\
\hline Instituto Millennium & 6 \\
\hline Instituto Liberdade & 3 \\
\hline IEE & 6 \\
\hline & Source: Created by the authors.
\end{tabular}

The FL gives these awards to sponsors and/or participants who share the same neoliberal view, amounting to a closed and homogeneous circuit. In other words, recipients are either affiliates of a neoliberal institute or sponsors, and the sponsors are affiliates of a neoliberal institute. ${ }^{16}$ Therefore, the awards are a means of self-legitimation by members and directors of neoliberal institutes.

\section{Conclusion}

The purpose of this study was to cast light on what is regarded as the main forum of ideas in Latin America. By gathering and analysing data from the FL and the IEE, we have sought to elucidate who participates in these events, who sponsors them, their themes, and which speakers receive awards.

It shows that the FL is not a 'forum of ideas', or a 'plural forum.' While efforts might have been made at the very beginning to incorporate speakers from different ideological traditions, this effort has diminished throughout the years. Currently, the FL is a forum of 'one idea' - an exhibitor of a neoliberal ideal, focusing on speakers that will corroborate this same world vision. The speakers are also not 'plural.' The vast majority are male, politicians, businessmen, professors, and members of neoliberal institutes in Brazil or abroad. The FL has been internationalising itself, but in a very specific way, by embracing a majority of US speakers. The only foreign sponsor is a US institution, the Atlas Network. Lastly, far from being a space of 'pluralities', the FL is a 'closed circuit in which the speakers and sponsors ultimately hand out awards to themselves.

Utilising corporate sponsorships and strategic support from an 'intelligentsia' that legitimises its ideas, the FL creates a space for promoting the neoliberal agenda and the concept of 'market civilisation.' It also promotes politicians who share its neoliberal beliefs, and propagates strategies for delegitimising governments and politicians who are hostile 
to the 'liberal' agenda. These efforts are supported and disseminated by media which cover the events and participate in them as well.

In the process, the FL works to subordinate an entire national political and economic system to a foreign hegemonic power. This is achieved via financial support from prominent businessmen with an interest in neoliberal economic policies; via the massive presence of US nationals at the events; via speakers' ties with US universities (notably the University of Chicago); and through the role of the Atlas Network.

As noted by neo-Gramscians such as Robert Cox, the dominance of the great powers is entrenched when subordinates feel compelled to promote ideologies that serve their interests, even though this may not be in the interests of the periphery. In mobilising this via a triad of politicians, financiers and academics, the FL is a compelling example. The conservative Richard Weaver (1948) was right: ideas do have consequences.

\section{Appendix 1 - Themes and panel titles at FL events}

\begin{tabular}{ll}
\hline $\begin{array}{l}\text { Fórum da } \\
\text { Liberdade }\end{array}$ & Event / panel titles \\
\hline I (1988) & $\begin{array}{l}\text { Questões Políticas, Econômicas e Sociais no Brasil } \\
\text { [Political, Economic and Social Issues in Brazil] }\end{array}$ \\
\hline II (1989) & $\begin{array}{l}\text { As Propostas dos Candidatos a Sucessão Presidencial no Brasil } \\
\text { [Proposals from Presidential Successor Candidates in Brazil] }\end{array}$ \\
\hline III (1990) & $\begin{array}{l}\text { A Busca da Modernidade: 0 Desafio Latino-Americano } \\
\text { [The Search for Modernity: The Latin-American Challenge] }\end{array}$ \\
\hline IV (1991) & $\begin{array}{l}\text { Os Caminhos para a Próxima Década: As soluções Liberais e Sociais-Democrata } \\
\text { [Roads to the Next Decade: Liberal and Social Democrat Solutions] }\end{array}$ \\
\hline V (1992) & $\begin{array}{l}\text { Estado ou Mercado: Quem melhor defende a ecologia? } \\
\text { [State or Market: Who best defends ecology?] }\end{array}$ \\
\hline VI (1993) & $\begin{array}{l}\text { 0 Desafio da Reforma Constitucional } \\
\text { [The Challenge of Constitutional Reform] }\end{array}$ \\
\hline VII (1994) & $\begin{array}{l}\text { A Educação em Crise } \\
\text { [Crisis in Education] }\end{array}$ \\
\hline VIII (1995) & $\begin{array}{l}\text { Globalização e Livre Comércio Internacional } \\
\text { [Globalization and International Free Market] }\end{array}$ \\
\hline IX (1996) & $\begin{array}{l}\text { Desafio Brasileiro: Custo Brasil } \\
\text { [Brazilian Challenge: The Brazil cost] }\end{array}$ \\
\hline X (1997) & $\begin{array}{l}\text { O Desafio de um Mundo sem Empregos } \\
\text { [The Challenge of a Jobless World] }\end{array}$ \\
\hline XI (1998) & $\begin{array}{l}\text { Os Limites do Poder: Poder e Sociedades } \\
\text { [The Limits of Power: Power and Societies] }\end{array}$ \\
\hline XII (1999) & $\begin{array}{l}\text { E Agora, Brasil? Caminhos para o Desenvolvimento } \\
\text { [What Now, Brazil? Roads to Development] }\end{array}$ \\
$\begin{array}{l}\text { 1000 Anos: 0 Brasil em Perspectiva: Onde é que Esta História Vai Parar? } \\
\text { [1000 Years: Brazil in perspective: Where will this story ends?] }\end{array}$ \\
\hline
\end{tabular} \begin{tabular}{l} 
\\
\hline
\end{tabular}




\begin{tabular}{|c|c|}
\hline $\begin{array}{l}\text { Fórum da } \\
\text { Liberdade }\end{array}$ & Event / panel titles \\
\hline XIV (2001) & $\begin{array}{l}\text { A Crise Social Brasileira: Causas, Desafios e Soluções } \\
\text { [The Brazilian Social Crisis: Causes, Challenges and Solutions] }\end{array}$ \\
\hline XV (2002) & $\begin{array}{l}\text { Os Desafios da Democracia no Século XXI } \\
\text { [Democracy's Challenges in the 21st Century] }\end{array}$ \\
\hline XVI (2003) & $\begin{array}{l}\text { Civilização ou Barbárie: Em que Mundo Vamos Viver? } \\
\text { [Civilisation or Barbarism: Which World Are We Going to Live in?] }\end{array}$ \\
\hline XVII (2004) & $\begin{array}{l}\text { Desenvolvimento e Liberdade } \\
\text { [Development and Liberty] }\end{array}$ \\
\hline XVIII (2005) & $\begin{array}{l}\text { A Cultura do Trabalho } \\
\text { [The Culture of Work] }\end{array}$ \\
\hline XIX (2006) & $\begin{array}{l}0 \text { Poder no Brasil: Quais os Direitos e Deveres dos Governos } \\
\text { [Power in Brazil: Governments' Rights and Duties] }\end{array}$ \\
\hline XX (2007) & $\begin{array}{l}\text { Propriedade e Desenvolvimento } \\
\text { [Property and Development] }\end{array}$ \\
\hline XXI (2008) & $\begin{array}{l}\text { Agora o Mercado é o Mundo } \\
\text { [Now the Market is the World] } \\
\text { Panel 1: Agora, Quem é o Mercado? [Now, Who Is the Market?] } \\
\text { Panel 2: Livre Comércio: Ameaça ou Oportunidade? [Free Market: Threat or Opportunity?] } \\
\text { Panel 3: Mercados Globais e Estados Nacionais [Global Markets and National States] } \\
\text { Panel 4: Aquecimento ou Histeria Global? [Global Warming or Hysteria?] } \\
\text { Panel 5: As Reformas para Aumentar a Competitividade [The Reforms to Increase Competi- } \\
\text { tiveness] } \\
\text { Special lecture: } 0 \text { Brasil no Mercado Global [Brazil in the Global Market] }\end{array}$ \\
\hline XXII (2009) & $\begin{array}{l}\text { Cultura da Liberdade } \\
\text { [Culture of Freedom] } \\
\text { Panel 1: Cultura da Liberdade [Culture of Freedom] } \\
\text { Panel 2: Liberdade e Protecionismo [Freedom and Protectionism] } \\
\text { Panel 3: Liberdade e Intervencionismo [Freedom and Interventionism] } \\
\text { Panel 4: Liberdade de Etnias [Freedom of Ethnicities] } \\
\text { Panel 5: Liberdade de Imprensa [Freedom of the Press] }\end{array}$ \\
\hline XXIII (2010) & $\begin{array}{l}\text { Seis Temas para Entender o Mundo } \\
\text { [Six Themes to Understand the World] } \\
\text { Panel 1: Capitalismo [Capitalism] } \\
\text { Panel 2: Socialismo [Socialism] } \\
\text { Panel 3: Inflação [Inflation] } \\
\text { Panel 4: Intervencionismo [Interventionism] } \\
\text { Panel 5: Investimento Estrangeiro [Foreign investment] }\end{array}$ \\
\hline XXIV (2011) & $\begin{array}{l}\text { Liberdade na Era Digital } \\
\text { [Freedom in the Digital Era] } \\
\text { Panel 1: Liberdade Individual: A Arte de Construir a Própria História [Individual Freedom: The } \\
\text { Art of Building Its Own History] } \\
\text { Panel 2: Tecnologia: Serviços e Oportunidades [Technology: Services and Opportunities] } \\
\text { Panel 3: Inovação e Tendências: Olhando o Futuro [Trends and Innovation: Looking for the } \\
\text { Future] } \\
\text { Panel 4: Tecnologia e Democracia: } 0 \text { Governo Nu [Democracy and Technology: The Naked } \\
\text { Government] } \\
\text { Panel 5: Os Desafios da Imprensa na Era Digital [Press Challenges in the Digital Era] } \\
\text { Panel 6: A Educação no Futuro [Education in the Future] } \\
\text { Panel 7: Livre Economia na Web [Free Economy in the Web] } \\
\text { Panel 8: Uma Nova Democracia Digital [A New Digital Democracy] }\end{array}$ \\
\hline
\end{tabular}




\begin{tabular}{|c|c|}
\hline $\begin{array}{l}\text { Fórum da } \\
\text { Liberdade }\end{array}$ & Event / panel titles \\
\hline XXV (2012) & $\begin{array}{l}\text { 2037: Que Brasil Será o Seu? } \\
\text { [2037: Which Brazil Will Be Yours?] } \\
\text { Panel 1: Que Brasil Será o Seu? [Which Brazil Will Be Yours?] } \\
\text { Panel 2: Empreendedores que Fazem o Futuro [Entrepreneurs Who Make the Future] } \\
\text { Panel 3: Portas de Acesso à Prosperidade [Access Doors to Prosperity] } \\
\text { Panel 4: Lições do Mundo para o Brasil [Lessons of the World to Brazil] } \\
\text { Panel 5: Corrupção e Desafios da Democracia Brasileira [Corruption and Brazilian Democracy } \\
\text { Challenges] } \\
\text { Panel 6: Educação: Obedecer, Pensar ou Criar? [Education: To Obey, to Think, or to Create?] } \\
\text { Panel 7: Drogas, Violência e Liberdade [Drugs, Violence, and Freedom] }\end{array}$ \\
\hline XXVI (2013) & $\begin{array}{l}0 \text { que se vê o que não se vê } \\
\text { [What we see and what we don't see] } \\
\text { Panel 1: Empreendedorismo: Há Empreendedorismo sem Lucro? [Entrepreneurship: Is There } \\
\text { Entrepreneurship without Profit?] } \\
\text { Panel 2: Liberdade de Imprensa: Qual o Preço do Silêncio? [Freedom of the Press: What is the } \\
\text { Price of Silence?] } \\
\text { Panel 3: Segurança Pública: Qual o Custo da Insegurança? [Public Security: What is the Price } \\
\text { of Insecurity?] } \\
\text { Panel 4: Protecionismo: Protegendo Quem de Quem? [Protectionism: Protecting Whom from } \\
\text { Whom?] } \\
\text { Panel 5: Falta de Infraestrutura: A Infraestrutura Pública É Gratuita? [Lack of Infrastructure: } \\
\text { Is Public Infrastructure Free?] } \\
\text { Panel 6: Educação Básica: Quais as Consequências da Ignorância? [Basic Education: What Are } \\
\text { the Consequences of Ignorance?] } \\
\text { Panel 7: Gasto Público: Quem Paga a Conta? [Public Waste: Who Pays the Bill?] }\end{array}$ \\
\hline XXVII (2014) & $\begin{array}{l}\text { Construindo Soluções } \\
\text { [Building Solutions] } \\
\text { Panel 1: Competitividade [Competitiveness] } \\
\text { Panel 2: Educação [Education] } \\
\text { Panel 3: Saúde [Health] } \\
\text { Panel 4: Estado de Direito e Democracia [Rule of Law and Democracy] } \\
\text { Panel 5: Finanças Públicas [Public Finances] } \\
\text { Panel 6: Livre Mercado [Free Market] }\end{array}$ \\
\hline $\begin{array}{l}\text { XXVIII } \\
\text { (2015) }\end{array}$ & $\begin{array}{l}\text { Caminhos para a Liberdade } \\
\text { [Roads to Freedom] } \\
\text { Panel 1: Educação e Meritocracia [Education and Meritocracy] } \\
\text { Panel 2: Caminhos para o Brasil [Roads to Brazil] } \\
\text { Panel 3: Livre Mercado [Free Market] } \\
\text { Panel 4: Empreendedorismo [Entrepreneurship] } \\
\text { Panel 5: Institutições [Institutions] } \\
\text { Panel 6: América Latina [Latin America] } \\
\text { Panel 7: Liberdade de Expressão: \#nasruaspelaliberdade [Freedom of Speech: \#on the streets } \\
\text { for liberty] }\end{array}$ \\
\hline XXIX (2016) & $\begin{array}{l}\text { Quem Move o Mundo? } \\
\text { [Who Moves the World?] } \\
\text { Panel 1: Definindo a Liberdade [Defining Freedom] } \\
\text { Panel 2: Terra Brasilis [Terra Brasilis] } \\
\text { Panel 3: Admirável Mundo Novo [Brave New World] } \\
\text { Panel 4: Competição e Atividade Empresarial [Competition and Business Activity] } \\
\text { Panel 5: Por que as Nações Fracassam? [Why Nations Fail?] } \\
\text { Panel 6: Anatomia do Estado [State's Anatomy] } \\
\text { Panel 7: Quem é John Galt? [Who is John Galt?] }\end{array}$ \\
\hline
\end{tabular}




\begin{tabular}{ll}
\hline $\begin{array}{c}\text { Fórum da } \\
\text { Liberdade }\end{array}$ & Event / panel titles \\
\hline & O Futuro da Democracia \\
& [The Future of Democracy] \\
& - Panel 1: Perspectivas para o Brasil [Prospects for Brazil] \\
& - Panel 2: Novos Tempos [New Times] \\
XXX (2017) & - Panel 3: Empreender, Criar e Inovar [Engaging, Creating and Innovating] \\
& - Panel 4: As Origens da Prosperidade [The Origins of Prosperity] \\
& - Panel 5: Economia: Liberdade ou Intervenção [Economy: Freedom or Intervention?] \\
& - Panel 6: Cultura da Democracia [Culture of Democracy] \\
& - Panel 7: Os Limites da Democracia [The Limits of Democracy] \\
& A Voz da Mudança \\
& [The Voice of Change] \\
& Panel 1: Um Novo Trajeto para a América Latina [A New Road to Latin America] \\
& Panel 2: Empreender para Mudar [Engaging to Change] \\
& Panel 3: Agentes de Mudança [Agents of Change] \\
& Panel 4: Politicamente Incorreto [Politically Incorrect] \\
& Panel 5: A Lei [The Law]
\end{tabular}

Source: Created by the authors.

\section{Notes}

1 Even though most of these think tanks regard themselves as 'liberal', we have chosen to use the term 'neoliberalism' in order to avoid misconceptions in the USA. These institutions used the term 'liberal' to denote the ideals of classical liberalism which, in Latin America, is associated with the Washington Consensus, while in the USA it is associated with economic conservatism. Given this, the term 'neoliberal' is associated with support for market economics, which Rick Fantasia (cited in Wacquant and Lins 2003: 21) defines as 'an example of business deregulation, privatisation of public services, fast growth in the service sector, technological innovation associated with it, and, more generally, of the vast practices taught to replace public interest by profit.

2 This and subsequent quotations from sources published in Portuguese have been translated by the authors.

3 On pedagogical colonisation, see Jauretche (1975) and Gullo (2018).

4 Instituto de Estudos Empresariais (RS), Instituto Liberdade (RS), Estudantes pela Liberade (MG), Instituto Atlantos (RS), Instituto de Formação de Líderes (MG, SP and SC), Instituto Liberal (RJ), Instituto Liberal de São Paulo (SP), Instituto Ludwig Von Mises Brasil (SP), Instituto Millenium (RJ), Instituto Líderes do Amanhã (ES), Livres (RJ), Mackenzie Center for Economic Freedom (SP), Students for Liberty Brasil (SP).

5 Funding is provided by USAID and the State Department via the National Endowment for Democracy (NED) (Atlas 2018; Fang 2017).

6 The sponsors include Koch Brothers, Exxon Mobil, MasterCard and Philip Morris, to name a few. Giant multinationals such as Pfizer, Procter and Gamble and Shell also contributeed to its foundation (Fang 2017). Alex Chafuen, president of the Atlas Network, has explained the lack of publicity and transparency about donations by major corporations as follows: 'Pfizer cannot finance research about health themes, and Exxon cannot pay for environmental thematics, but libertarian think tanks such as the Atlas Network can not only work on these themes, but will have more credibility while doing so, and garner more media coverage' (cited in Aharonian and Rangel 2018).

7 In Brazil, we have to consider the relationship between the Movimento Brasil Livre (MBL), the Atlas Network, and the role played by the group involved in the impeachment of Dilma Rousseff. In Argentina, the Pensar organisation, linked to Atlas, played a role in the anti-Kirchner movement, which was later incorporated into Macri's party. In Honduras, the Fundação Eleutera, an active player in the Honduran coup, has maintained close links with Atlas, and has even received funding from it. Lastly, since 1998 the Venezuelan Cedice Libertad, the Atlas branch in Caracas, has received financial support from its North 
American partner while conducting a campaigning for a 'change in government' (Aharonian and Rangel 2018).

8 Fernando Schuler, a member of Instituto Millenium, an Atlas partner in Brazil, has remarked that: 'With the help of technology, people can participate directly, organising - via WhatsApp, Facebook and YouTube - a type of low-cost public protest' (cited in Fang 2017: np).

9 For the participation of the Atlas Network in the destabilisation of leftist governments in Bolivia, Chile, Honduras, Venezuela, Argentina and Brazil, see Fang (2017).

10 The actual number may be higher since some groups, including the MBL - the political arm of Estudantes pela Liberdad - were created by Atlas partners (Atlas 2015). However, if they wish to play a direct role in politics, they will have to loosen their ties with Atlas, as US legislation prohibits the disbursement of public funds to political groupings in other countries.

11 The founders include members of the Ling family, also members of Grupo Evora. William Ling helped to establish the IEE, and organised the first FL event in 1988. His brother, Winston, is the founder of the Instituto Liberdade, also based in Porto Alegre. His son, Antony, is an Estudantes pela Liberdade affiliate.

12 We share the understanding that the neoliberal ideal is rooted in classical liberalism. It has been in practical use since the 1980s, culminating in the Washington Consensus. In Latin America, neoliberalism upholds the central theses of classical liberalism, advocating small governments and the defence of private property.

13 The IEE has described the Forum as a space for 'promoting the liberty of ideas' (see IEE 2017).

14 Columbia University is in second place, with 24 speakers.

15 In compiling our database, we took multiple occupations into consideration. Therefore, there are some overlaps.

16 Some examples of this closed and homogeneous circuit among sponsors, speakers and the awarded are: Carlos Biederman, director of CMPC: speaker in 1988, FL director in 1988, IEE president in 1989, sponsor in 2016-2018; Walter Lídio and Carlos Anton Karl Biederman, awarded in 2015 and 1999 respectively; José Galló, director of Renner: speaker in 2007, awarded in 2016, sponsor in 2014-2018; Alex Chafuen, Atlas president: speaker in 2006 and 2015; Tom Palmer, Atlas vice-president: speaker in 2012, 2013 and 2017; sponsor in 2014-2018.

\section{References}

Acharya, A and B Buzan. 2010. Non-Western International Relations Theory. London: Routledge. Aharonian, A and A Rangel. 2018. 'Rede Atlas: A Força-tarefa dos "Libertários de Ultra Direita” por uma Ofensa Capitalista na América Latina.' Carta Maior, 17 August.

Amaral, M. 2015. 'Como Organizações dos EUA financiam grupos de direita no Brasil para defender suas bandeiras'. Diário do Centro do Mundo, 25 Junho.

Atlas Network. 2015. Students for Liberty Plays a Strong Role in Free Brazil Movement. At https:// www.atlasnetwork.org/news/article/students-for-liberty-plays-strong-role-in-free-brazil-movement [Accessed on 12 August 2018].

Bandeira, L A M. 2018. A Desordem Mundial. Rio de Janeiro: Civilização Brasileira.

Bourdieu, P and L Wacquant. 1992. An Invitation to Reflexive Sociology. Chicago: University of Chicago.

Brzezinski, Z. 1998. El Gran Tablero Mundial. Barcelona: Paidós.

Casimiro, F H. 2016. A Nova Direita no Brasil: Aparelhos de Ação Político-Ideológica e a Atualização das Estratégias de Dominação Burguesa. Ph.D. Thesis. Universidade Federal Fluminense, Rio de Janeiro, Brazil.

Cox, R. 1981. 'Social Forces, States and World Orders'. Millenium 10 (2): 126-155. 
Dixon, E D. 2016. Atlas Story: Brazil's Ideological Crossroads. At https://www.atlasnetwork.org/news/ article/atlas-networks-top-stories-of-2016 [Accessed on 6 July 2018].

Fang, L. 2017. 'Esferas de Influência.' The Intercept [online]. At https://theintercept.com/2017/08/11/ esfera-de-influencia-como-os-libertarios-americanos-estao-reinventando-a-politica-latino-americana/ [Accessed on 16 September 2017].

Fischer, K and D Plehwe. 2013. 'Redes de Think Tanks e Intelectuales de Derecha en América Latina.' Nueva Sociedad $245: 70-86$.

FL. 2018. Fórum da Liberdade. At https://forumdaliberdade.com.br/2018/ [Accessed on 10 February 2018].

Gill, S. 1995. 'Globalization, Market Civilisation, and Disciplinary Neoliberalism.' Millennium 24 (3): 399-423.

Gramsci, A. 1971. Selections from the Prision Notebooks. New York: International Publishers. 2001. Cadernos do Cárcere, Vol. 2. Rio de Janeiro: Civilização Brasileira.

Gros, D. 2003. 'Organizações Empresariais e Ação Política no Brasil a partir dos Anos 80.' Civitas 3 (2): 273-300.

Gullo, M. 2018. Relaciones Internacionales: Una Teoría Crítica Desde la Periferia Sudamericana. Buenos Aires: Editorial Biblos.

Hoffman, S. 1977. 'An American social science: International Relations.' Daedalus 106 (3): 41-60.

Instituto de Estudos Empresariais (IEE). 2017. 'Instituto de Estudos Empresariais.' At http://iee.com. br [Accessed on 09 September 2017].

Jauretche, A. 1975. Los Profetas del Odio y la Yapa: La Colonización Pedagógica. Buenos Aires: Pena Lillo.

Nye, J. 2006. 'Política de Seducción no de Garrote.' Clarín, 11 September.

Tickner, A. 2003. 'Seeing IR Differently: Notes from the Third World.' Millennium 32 (2): 295-324.

Tickner, A and C Inoue. 2016. 'Many Worlds, Many Theories?' Revista Brasileira de Política Internacional 59 (2): 1-4.

Villa, R D, A Tickner, M Souza and Y Masmeda. 2017. 'Comunidades de Relações Internacionais na América Latina: Uma Análise das Tendências a partir do TRIP 2014.' Carta Internacional 12 (1): 224-256.

Wacquant, L and D Lins (eds). 2003. Repensar os Estados Unidos: Por uma sociologia do superpoder. Campinas: Papirus. 


\section{About the authors}

Camila Vidal is an International Relations Professor in the Economy and International Relations Department of the Universidade Federal de Santa Catarina (UFSC). She holds a doctorate and master's degree from the Programa de Pós-Graduação em Ciência Política (Universidade Federal do Rio Grande do Sul) and an undergraduate degree in International Relations from Florida International University. She leads two research groups: 'O Poder das ideias e a formação de institutos liberais na América Latina' and 'Intervenções dos EUA na América Latina' (part of GEPPIC/UFSC). Recent publications include 'Políticas Extremadas: Polarização Partidária e Questões Sociais nos Estados Unidos', Revista de Sociologia e Política, 2018; 'and 'Polarização Partidária e Política Externa nos Estados Unidos', RBCP, 2018.

Jahde Lopez is an undergraduate student of International Relations at Universidade Federal do Rio Grande (FURG) where she participates in the Maritime Policy and Law Research Laboratory (LABMAR). She held a scholarship as a scientific initiation scholar (FAPERGS) in 2017-2019 and is a member of the research group 'O Poder das ideias e a formação de institutos liberais na América Latina.' Her main research interests are US influence in Latin America and Dependency Theory. Recent published articles and book chapters include 'Atuação de corporações estadunidenses no período ditatorial da América do Sul', Estudos em Relações Internacionais (Rio Grande: FURG), 2018; and 'A securitização político-econômica na América do Sul e seus reflexos na Argentina durante o regime military', Interação, 2017.

Luan Corrêa Brum holds a Bachelor's degree in International Relations from the Universidade Federal do Rio Grande (FURG). He previously worked in the Research Group entitled 'The Formation of Normative Orders in International Relations.' He held a Scientific Initiation Scholarship (CNPq) in 2016-2018 and an Initiation in Technological Development and Innovation scholarship (PIBITI) in 2018-2019. He is part of the Research Group 'O Poder das ideias e a formação de institutos liberais na América Latina.' His main research interests are the history of North American foreign policy, neoliberalism in Latin America, and the influence of the USA on Latin American countries. 


\section{Poder das Idéias: 0 Fórum da Liberdade (FL) (1988-2018)}

Resumo: O trabalho aqui apresentado estuda o Fórum da Liberdade (FL), organizado pelo think tank brasileiro Instituto Brasileiro de Estudos Empresariais, parceiro da Rede Atlas. Do ponto de vista da teoria crítica, o objetivo deste trabalho é apresentar a hegemonia dos EUA no campo das ideias. A partir de uma análise de todas as edições da FL (1988-2018), pretendemos observar essa hegemonia como uma baseada na promoção do modelo econômico neoliberal. Através do estudo de vários dados reunidos e publicados pela FL, construímos uma narrativa para as pessoas que fazem palestras durante esses eventos, os patrocinadores, os temas abordados principalmente e os vencedores dos prêmios. Como resultado, descobrimos que: a) a FL privilegia temas e palestrantes que apoiam o ideal neoliberal - principalmente homens, políticos, empresários e membros de think tanks neoliberais no Brasil e no exterior; b) o FL também se internacionalizou, abraçando a maioria absoluta de oradores dos EUA e fortalecendo os laços com seu principal parceiro, a Rede Atlas da América do Norte; c) o FL contribui para a construção de uma plataforma eleitoral que privilegia os políticos ligados aos seus ideais econômicos; e d) com o apoio financeiro de empreendedores que possibilitam os eventos anuais e de uma 'intelligentsia' que legitima as ideias aqui apresentadas, a FL entrega e se propaga à agenda neoliberal dos EUA.

Palavras-chave: Fórum da Liberdade; think tanks; Rede Atlas; neoliberalismo; Teoria Crítica.

Received on 2 April 2019, and approved for publication on 6 January 2020. 